\title{
Nutrient Content of Cocoa Pod (Theobroma cocoa) Fermentation with Aspergillus niger Addition
}

\author{
Engkus Ainul Yakin ${ }^{1}$ and Ahimsa Kandi Sariri ${ }^{1}$ \\ ${ }^{1}$ Faculty of Agriculture, Universitas Veteran Bangun Nusantara, Sukoharjo, Indonesia \\ Corresponding author : engkus_ainul@yahoo.com
}

\begin{abstract}
The study was conducted to determine the increase in nutrient content and decrease in the lignin content of cocoa pod fermented with Aspergillus niger. The research method used three treatments and four replications. T0 $=$ cocoa pod fermented without the addition of Aspergillus niger, $\mathrm{T} 1=$ cocoa pod fermented with the addition of $1 \%$ Aspergillus niger, and T2 = cocoa pod fermented with the addition of $2 \%$ Aspergillus niger. Fresh cocoa pod was chopped in 1-2 cm size. Cocoa pod chopped and dried, some added with Aspergillus niger. The mixture is put into an aerobic container for 7 days. The variables observed included dry matter, crude protein, crude fiber, and crude fat. This study was designed using a complete randomized design research design with one-way ANOVA analysis. Significant variables were followed by Duncan's multiple range test (Duncan multiple range test / DMRT). The results of the study showed significantly different results in all treatments. It was concluded that the fermentation with addition Aspergillus niger until 2\% decrease crude protein, crude fiber, and crude fat on cocoa pod fermentation.
\end{abstract}

Keywords : Aspergillus niger, cocoa pod, fermentation

\section{Introduction}

The main obstacle of livestock farmers especially in increasing livestock population is limited feed. Expansion of the area for planting grass as ruminant feed is very difficult, because the land conversion is very high. Considering the lack of grazing land, the effort to use agricultural waste for food needs to be combined with other ingredients that are not yet commonly used as feed.

Food crops and plantations have an important and potential role in providing forage feed for ruminants such as cattle, goats, sheep and buffaloes, especially in the dry season. In the dry season, forage is disturbed by growth, so that forage available is not good in terms of quantity and quality. Even in certain areas, fodder grass will dry and die, causing a forage feed crisis. In addition, the ruminant livestock maintenance system is still largely dependent on forage feed in the form of grasses and other forage feed with little or no additional feed.

To overcome the problem of lack of forage feed, farmers are expected to be able to utilize agricultural waste that is quite widely available around it, including cocoa pods, sugar cane shoots, rice straw, corn straw, soybean straw and ground nut straw through certain treatments. 
Cocoa pod, has an important role and has the potential to provide ruminant feed, especially during the dry season. Utilization of cocoa pod as ruminants feed in the field is still not optimal, some are disposed of or spread under cocoa trees. Cocoa pod is suitable for consumption by ruminants only three days after harvest. Munier (2009) reported that cocoa pod was feasible to be consumed by ruminants until the third day after harvest, after the fourth day the cocoa pod had begun to be overgrown with fungi and smelled of acid.

The use of cocoa pods as animal feed can be given in the form of fresh or in the form of flour after processing. The results showed that fresh cocoa rind which was dried with sunlight and then milled could then be used as animal feed ingredients.

Cocoa pod is an agro-industrial waste produced by cocoa (Theobroma cacao L.) cocoa fruit which consists of $74 \%$ fruit peels, $2 \%$ placenta and $24 \%$ seeds. Proximate analysis results contain 22\% protein and 3-9\% fat (Nasrullah et al.). Munier (2009) reported that the cocoa pod contains nutritional content of dry matter $18.7 \%$, crude protein $9.9 \%$, crude fiber $32.9 \%$ and crude fat $9,2 \%$.

The use of cocoa pod directly is not good because it has low palatability due to the toxicity of Theobromine which smells of alcohol. The effort to overcome this is by processing cocoa pod into flour and then fermented with mold services. From the results of research conducted on sheep, the use of cocoa pod can be used as a substitute for supplements as much as $15 \%$ or $5 \%$ of the ration. Preferably before being used as animal feed, cocoa pods need to be fermented in advance to reduce lignin levels that are difficult to digest by animals and to increase protein levels from 6-8\% to $12-15 \%$.

The purpose of this study is to assess the nutrient content and decrease in lignin content in the skin of fermented cocoa fruit. It is expected that from this research will be produced the right footing method in processing agricultural waste of cocoa pods using the services of mold so that later can be used for further research if given to ruminants.

\section{Materials and Methods}

The material used was fresh cocoa pod, Aspergillus niger isolates, disinfectants, alcohols, chemicals for proximate analysis. The tool used is a capacity scale of $10 \mathrm{~kg}$ with a sensitivity of $0.1 \mathrm{~kg}$, electric scales with sensitivity of $0.001 \mathrm{~g}$, digital thermometers, hygrometers to measure the humidity of the fermentation chamber, oven, test tube, petri disk, oil, aluminum foil autoclave, cotton and a set of equipment laboratory for proximate analysis.

Fresh cocoa pod collected from Girimarto Subdistrict, Wonogiri Regency was brought to the laboratory to be fermented. Cocoa pod was fermented in a plastic box and aeration is maintained by punching holes in the bottom and side of the box. One hundred grams of cocoa pod is used for each plastic box and sprinkled with Aspergillus niger. The fermentation chamber temperature is maintained in the range of $28-30^{\circ} \mathrm{C}$ with humidity of $75-85 \%$ so that the growth of Apergillus niger is optimal. Fermentation is carried out for 7 days.

The design of the study uses a completely randomized design of unidirectional patterns. Three treatments with four replications were used, namely: T0 $=$ cocoa pod fermentation without the addition of Aspergillus niger, $\mathrm{T} 1=$ cocoa pod fermentation 
with the addition of 5\% Aspergillus niger and T2 = cocoa pod fermented with the addition of $10 \%$ Aspergillus niger.

Parameters observed were Dry Matter, Crude Protein, Crude Fat, and Crude Fiber. The data obtained were analyzed using variance analysis (ANOVA) in unidirectional pattern and continued with Duncan's Multiple Range Test (DMRT) (Christensen, 1996) if there were differences.

\section{Result and Discussions}

The average chemical content of cocoa pod fermentation after treatments during the study listed in the table.

\begin{tabular}{lccc}
\hline \multirow{2}{*}{ Variable (\%) } & \multicolumn{3}{c}{ Treatment } \\
\cline { 2 - 4 } & $\mathrm{T} 0$ & $\mathrm{~T} 1$ & $\mathrm{~T} 2$ \\
\hline & & & \\
dry matter & $27,31^{\mathrm{b}} \pm 0,12$ & $22,46^{\mathrm{a}} \pm 0,92$ & $22,26^{\mathrm{a}} \pm 0,51$ \\
crude protein & $2,45^{\mathrm{b}} \pm 0,29$ & $1,67^{\mathrm{a}} \pm 0,24$ & $2,05^{\mathrm{ab}} \pm 0,26$ \\
crude fat & $1,02^{\mathrm{b}} \pm 0,12$ & $0,68^{\mathrm{a}} \pm 0,69$ & $0,65^{\mathrm{a}} \pm 0,03$ \\
crude fiber & $8,37^{\mathrm{c}} \pm 0,52$ & $5,41^{\mathrm{a}} \pm 0,13$ & $7,01^{\mathrm{b}} \pm 0,33$ \\
\multicolumn{4}{c}{} \\
\hline \multicolumn{3}{c}{$, \mathrm{b}, \mathrm{c}$ Superscript on the same row shows different significant $(\mathrm{P}<0,05)$}
\end{tabular}

\section{Dry matter}

The results of the dry matter proximate average (DM) are listed in the table. Treatment of P0 shows results that are significantly different when compared to P1 and $\mathrm{P} 2$, while $\mathrm{P} 1$ and $\mathrm{P} 2$ show different results that are not real.

When viewed from the average $\mathrm{DM}$, the three treatments were $\mathrm{T} 0=27.31 \pm 0.12$, $\mathrm{T} 1=22.46 \pm 0.92$, and $\mathrm{T} 2=22.26 \pm 0.51 \%$. This figure shows that the DM content in treatment $\mathrm{T} 1$ and $\mathrm{T} 2$ is lower than that of T0. This can occur because the treatment of T1 and T2 given the addition of Aspergillus niger shows a decrease in DM. DM of cocoa pod BK content after experiencing a fermentation process has decreased. Lignin as a component of fiber that can not be used as mold as the main energy source. Therefore mold uses other organic matter from the substrate and results in changes in DM and OM [4]. Furthermore, according to (Suparjo et al., 2009) stated that the decrease in DM cocoa pod which was fermented by using Phanerochaete chrysosporium for 5 days was 5.52\%. This is due to the addition of Manganese $(\mathrm{Mg})$ mineral to the cocoa pod substrate. The function of this mineral can increase the growth rate and extend the mold mycelium, with the addition of this mineral, the use of DM is more efficient.

\section{Crude protein}

The results of the proximate mean of crude protein are listed in the table. Treatment of T0 showed results that were significantly different when compared to T1, while $\mathrm{T} 2$ showed different results which were not significant when compared to T0 and T1. 
When viewed from the average $\mathrm{CP}$ the treatment proximate analysis are $\mathrm{T} 0=2.45$ $\pm 0.29, \mathrm{~T} 1=1.67 \pm 0.24$, and $\mathrm{T} 2=2.05 \pm 0.26 \%$. This figure shows that $\mathrm{CP}$ in $\mathrm{T} 1$ and $\mathrm{T} 2$ is lower than T0. This shows that in the treatment of T1 and T2 which was given the addition of Aspergillus niger did not give an increase in $\mathrm{CP}$, precisely $\mathrm{T} 0$ which was not given the addition of Aspergillus niger give a higher $\mathrm{CP}$ content compared to $\mathrm{T} 1$ and $\mathrm{T} 2$.

The results of this study are lower than the results of the research previously reported. Laconi (1998) reported that cocoa pod fermented using Phanerochaete chrysosporium fungi which added molasses $3 \%$ of the weight of the media is by changing towards an increase in CP content of 20.72\%. While (Sutikno et al., 1994) reported that fermented cocoa pod using Aspergillus niger with the addition of urea and minerals significantly affected the increase in CP content from $5.88 \%$ to $10.73 \%$ in 4 days fermentation or an increase of $47.91 \%$. Research report (Lateef et al., 2008) stated that on the same media using Rhizopus stolonifer LAU 07 mold and given $20 \%$ sucrose with changes in CP increase to $95 \%$. This shows that the addition of urea, minerals and available carbohydrates can further improve mold performance in protease enzymatic processes followed by an increase in optimal CP content.

\section{Crude Fat}

The results of the crude fat proximate average are listed in the table. Treatment of $\mathrm{T} 0$ shows results that are significantly different when compared to $\mathrm{T} 1$ and $\mathrm{T} 2$, while $\mathrm{T} 1$ and $\mathrm{T} 2$ show different results that are not real.

When viewed from the average ccrude fat the treatments are $\mathrm{T} 0=1.02 \pm 0.12, \mathrm{~T} 1$ $=0.68 \pm 0.69$, and $\mathrm{T} 2=0.65 \pm 0.03 \%$. This figure shows that crude fat in $\mathrm{T} 1$ and $\mathrm{T} 2$ is lower than T0. This shows that in the treatment of P1 and P2 which were given the addition of Aspergillus niger did not give an increase in the crude fat, in fact T0 which was not given the addition of Aspergillus niger give higher crude fat content compared to T1 and T2. This is because the mold uses crude fat as an energy source. Fat has the main function as a backup energy in the form of triglycerides (Toha et al., 2005). According to (Hamid et al., 1999) that the lipase enzyme in Aspergillus niger has a role in hydrolyzing fat into glycerol and fatty acids in the presence of water molecules. This mold activity has caused a decrease in the content of the cocoapod crude fat in fermentation using Aspergillus niger.

The high decrease of crude fat of cocoa pod in this study was due to the limited energy available for mold to describe fiber fractions and alkaloids of cocoa pod so that crude fat was used as an energy source.

\section{Crude fiber}

Proximate average results of crude fiber is listed in the table. In all treatments showed significantly different results. When viewed from the average CF the treatments were $\mathrm{T} 0=8.37 \pm 0.52, \mathrm{~T} 1=5.41 \pm 0.13$, and $\mathrm{T} 2=7.01 \pm 0.33 \%$. This figure shows that the proximate $\mathrm{CF}$ in treatment $\mathrm{T} 0, \mathrm{~T} 1$ and $\mathrm{T} 2$ shows a significant difference between all treatments. $\mathrm{T} 1$ treatment $\mathrm{CF}$ is lower than $\mathrm{T} 0$ and $\mathrm{T} 2$. The addition of 5\% Aspergillus niger in cocoa pods fermentation give better results compared to $10 \%$ or without the addition of Aspergillus niger to crude fiber. 
Fermentation in this study only uses Aspergillus niger without the addition of other additives, so that when compared with similar studies using additives shows the results of different CF of cocoa pod. Alemawor et al. (2009) reported that there was a decrease in the content of cocoa pod by $7.64 \%$ using Aspergillus spp and added glucanase and xylanase enzymes. According to (Smith, 2002) that the urea solution serves to stretch or describe the lignohemiselulose and lignocellulose bonds in agricultural waste. Laconi et al., (1998) study found that there was a decrease of $18.16 \%$ in the content of $\mathrm{CF}$ of cocoa pod by using Phanerochaete chrysosporium mold, 5-7 $\mathrm{mm}$ cocoa pod chopped particles and 3\% molasses added from the total media.

Decrease in the content of cocoa pod is more influenced by the activity of enzymes produced by Aspergillus niger. Aspergillus niger produces various enzymes such as mannase enzyme, cellulase and other carbohydrate-breaking enzymes so that in the fermentation process this mold is able to decompose the fiber more optimally (Srinivasan et al., 1995).

\section{Conclusion}

Based on the research results can be concluded that the fermentation with addition Aspergillus niger until 2\% decrease crude protein, crude fiber, and crude fat on cocoa pod fermentation.

\section{References}

Munier, F.F. 2009. Potensi ketersediaan kulit buah kakao (Theobroma cacao L.) sebagai sumber pakan alternatif untuk ternak ruminansia di Darah Istimewa Yogyakarta. Pros. Sem. Nas. Teknologi Peterrnakan dan Veteriner, Bogor 13-14 Agustus 2009. 752-759.

Nasrullah dan A. Ella. 1993. Limbah Pertanian dan Prospeknya Sebagai Sumber Pakan Ternak di Sulawesi Selatan. Makalah. Ujung Pandang,.

Christensen, R. 1996. Analysis of variance, Design and Regession : Applied Statistical Methods. Chapman and Hall. London.

Suparjo, K.G. Wiryawan, E.B. Laconi dan D Mangunwidjaja. 2009. Perubahan komposisi kimia kulit buah kakao akibat penambahan mangan dan kalsium dalam biokonversi dengan kapang Phanerocahete chrysosporium. Media Peternakan. 32. (3) : 203-210.

Laconi, E.B. 1998.Peningkatan Mutu Pod Cacao Melalui Amoniasi dengan Urea dan Biofermentasi dengan Phanerochaete chrysosporium serta Penjabarannya ke dalam Formulasi Ransum Ruminansia. Disertasi. Program Pascasarjana Institut Pertanian Bogor, Bogor.

Sutikno,,A.I., T. Haryati dan J. Darma. 1994. Perbaikan kualitas gizi pod coklat melalui proses fermantasi. Buku 2. Pros. Sem. Sains dan Teknologi Peternakan. Pengolahan dan dan Komunikasi Hasil-Hasil Penelitian, Ciawi-Bogor 25-26 Januari 1994. Balitnak, Puslitbangnak., Badan Litbangtan., Bogor. 753-76. 
Lateef, A., Oloke, E.B.G. Kana, S.O. Oyeniyi, O.R. Onifade, A.O. Oyeleye, O.C. Olasadu, and A.O. Oyelami. 2008. Improving the quality of agro-wastes by solidstate fermentatiton; Enhanced antioxidant activities and nutritional qualities. DIG World J. Microbiol. Biotechnol,. DOI : 10.1007/s11274-008-9749-8. 24 : 23692374.

Toha, A.H.A. 2005. Biokimia : Metabolisme Biomolekul. Cetakan Kedua. Alfabeta, Bandung. pp 99-121.

Hamid, H., T. Purwadaria, T. Haryati dan P. Sinurat. 1999. Perubahan nilai bilangan peroksida bungkil kelapa dalam proses penyimpanan dan fermentasi dengan Aspergillus niger. JITV 4 : 101-106.

Alemawor, F., V.P. Dzogbefia, E.O.K. Oddoye and JJ.H. Oldham. 2009. Enzyme cocktail for enhancing poultry utilization of cocoa pod husk composition. Scientific Research and Essay. 4 (6) : 555-559.

Smith, T. 2002. On-farm treatment of straw and stover with urea. Proc. Of The Final Review Meeting of an IAEA Technical Co-Operation Regional AFRA Project. Cairo Egypt. 25-29 Nov 2000. Oraganized by FAO/IAEA Division of Nuclear Tecniques in Food and Agriculture. pp 15-22.

Srinivasan, C, T.M.D. Souza, K. Boominathan, and C.A. Reddy. 1995. Demonstration of Laccase in the White Rot Basidiomycete Phanerochaete chrysosporium. Aplied and Environmental Microbiology, 61 (2) : 4274-4277. 